\title{
THE POTENTIALLY TOXIC BENTHIC DINOFLAGELLATES ON MACROALGAE AT THE REEF FLAT OF SERIBU ISLANDS, NORTH JAKARTA - INDONESIA
}

\author{
Riani Widiarti ${ }^{1, *}$, Murtiningsih ${ }^{2}$, Suwarti ${ }^{2}$, Ahmad Mutaqin², Gud Elina Kurnia ${ }^{2}$ \\ 1) Centre for Marine Studies, Faculty of Mathematics and Natural Sciences \\ University of Indonesia \\ 2) National Centre for Fish Inspection and Quality Control, \\ Ministry of Marine Affairs and Fisheries \\ ${ }^{*}$ e-mail: rianiwid@yahoo.co.id
}

\begin{abstract}
The Ciguatera Fish Poisoning (CFP) causing microorganisms were observed at the reef flat of Penjaliran Barat Islands and Pramuka Islands District, Seribu Island National Park, North Jakarta, Indonesia. Of the samples collected, four potentially toxic benthic dinoflagellates species were found, which are Gambierdiscus toxicus, Prorocentrum concavum, Prorocentrum lima, and Ostreopsis lenticularis. The dinoflagellates were found attached on the brown macroalgae Padina and Sargassum. Most of the benthic dinoflagellates from both locations were found in Pramuka Islands District, the inhabited islands where human activities which could damage the coral reef areas were relatively high. Beside the macroalgae substrate preference of each dinoflagellate species, several environmental factors were also obtained in this research.
\end{abstract}

Keywords: Benthic Dinoflagellates, Ciguatera Fish Poisoning, Coral reef disturbance, Macroalgae substrate specificity.

\section{INTRODUCTION}

Ciguatera Fish Poisoning (CFP) is a poisoning syndrome acquired by human and other mammals following the ingestion of various tropical marine fishes associated with coral reefs (de Sylva, 1994; Randall, 1958). The symptoms of CFP are: gastrointestinal symptoms including diarrhea, nausea, vomiting, and abdominal pains; neurological symptoms including hot-cold inversion (reversal of sensation), joint and muscular aches, tingling sensations like "pins and needles", numbness of lips and tongue, itching, and hypotension (Ahmed, 1991 and Calvert, 1991 in de Sylva, 1994).

Randall (1958) found that the ciguatera toxin was produced by a benthic micro-organism which was first ingested by herbivorous fishes or detritusfeeding fishes, then transferred to larger carnivores (de Sylva, 1994). Ahmed (1991) also stated that fishes which eating algae on which these benthic microorganisms grow become toxic, and this effect is biomagnified through the food chain, so that the largest predatory fishes become the most toxic (de Sylva, 1994). The ciguatera toxins are believed to originate from several species of dinoflagellates, namely Gambierdiscus toxicus, Ostreopsis lenticularis, O. siamensis, Prorocentrum lima, $P$. concavum, $P$. mexicanum, Amphidinium carterae, and A. klebsii. These dinoflagellates can grow on various species of attached red, brown, and green macroalgae.

The increasing of CFP cases in one location could be caused by: increases in the sea surface temperature due to global warming; eutrophication by human activities; anthropogenic alterations such as dredging, filling, and coral reef destruction. The damage to coral reefs, which mostly caused by human activities (such as anchoring, construction, and dumping), are potentially present new surfaces for macroalgae which CFP causing dinoflagellates seem to prefer (de Sylva, 1994).

Indonesia consists of thousand small islands, which are surrounded by coral reefs. One of the islands, the Seribu Islands, is located on the 
northwest of Jakarta, the capital city of Indonesia. The area has been long receiving pressure from various human activities. Coral reefs disturbance, namely fish bombing and poisoning, boat anchoring, or coral collection for souvenir and construction, has reduced the coral coverage in that area with average number between $24,6-34,4 \%$ (Estradiveri and Yusri, 2006). The percentage number showed that the coral coverage is in fair condition (Coremap, 2006). With a great decreasing of coral reef condition in Seribu Islands, there is a strong possibility for the existence of CFP causing dinoflagellates in the waters.

\section{MATERIALS AND METHODS}

\section{Sampling location}

Sampling was conducted in Seribu Islands area, which is located between $4^{\circ}-6^{\circ} \mathrm{S}$ and $106^{\circ}$ $-107^{\circ}$ E. Samples were obtained from two locations. First location was in Penjaliran Island, which is located in the north end of Seribu Islands and included in the Core Zone area of the Seribu Islands National Park. The second location was in Pramuka Islands District, consist of three small islands, located in the middle and included in the Inhabited Zone area of the National Park (Fig. 1).

\section{Sample collection and observation}

Macro algae of Padina spp. and Sargassum spp. were harvested by random sampling in the reef flat of both locations. Thallus of the macroalgae were cut by knife, and put inside the plastic jars containing seawater. All macroalgae inside the plastic jars were shaken vigorously, and preserved in $5 \%$ formalin/ seawater. The seawater was then filtered through a series of sieves (125 and $20 \mu \mathrm{m})$. The upper sieve, with $125 \mu \mathrm{m}$ pore size, was used to filter detritus and sand granules.

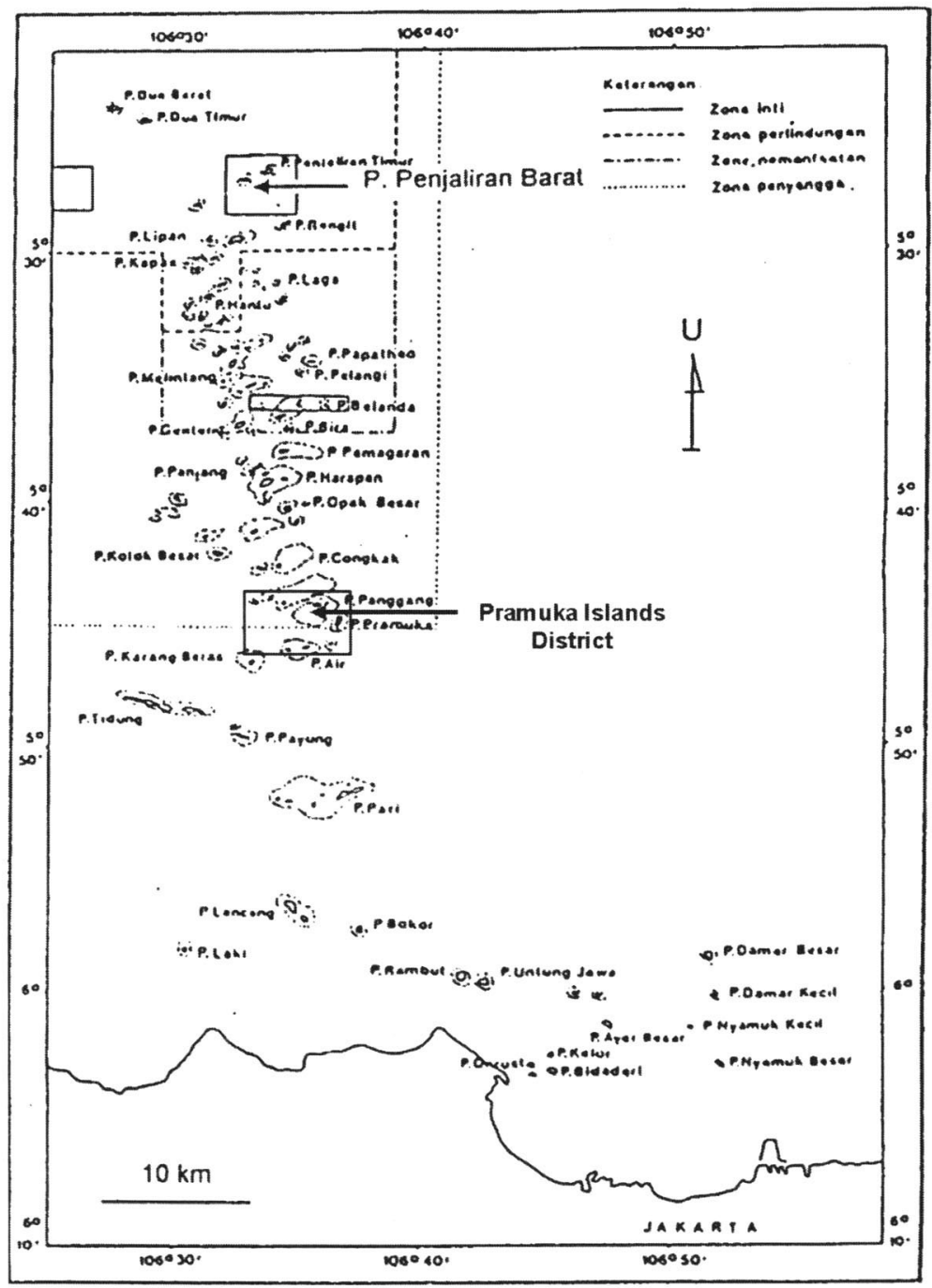

Figure 1. The location of Penjaliran Barat Island and Pramuka Islands District at Kepulauan Seribu National Park. 
The resulted residue on lower sieves $(20 \mu \mathrm{m})$ was then washed by filtered seawater. Suspension of $1 \mathrm{ml}$ was put inside a Sedgewick rafter cell for an observation under light microscope with $10 \times 10$ magnifications. The density of dinoflagellate cells is expressed as the number of cells/ $100 \mathrm{ml}$ of macroalgae wet volume.

\section{Environmental parameters measurement}

The environmental parameters were also measured during macroalgae sampling, which are: water transparency using sechi disc, water salinity using refractometer, and water surface temperature using thermometer.

\section{RESULTS AND DISCUSSION}

Four potentially toxic species which may contribute to ciguatera were found in this research, namely Gambierdiscus toxicus (Fig. 2), Ostreopsis lenticularis (Fig. 3), Prorocentrum concavum, and Prorocentrum lima (Fig. 4), which were found attached in brown macroalgae Sargassum spp. and Padina spp. The density of four toxic benthic dinoflagellates cells per 100 millimeter of macroalgae wet volume is represented in the Table 1.

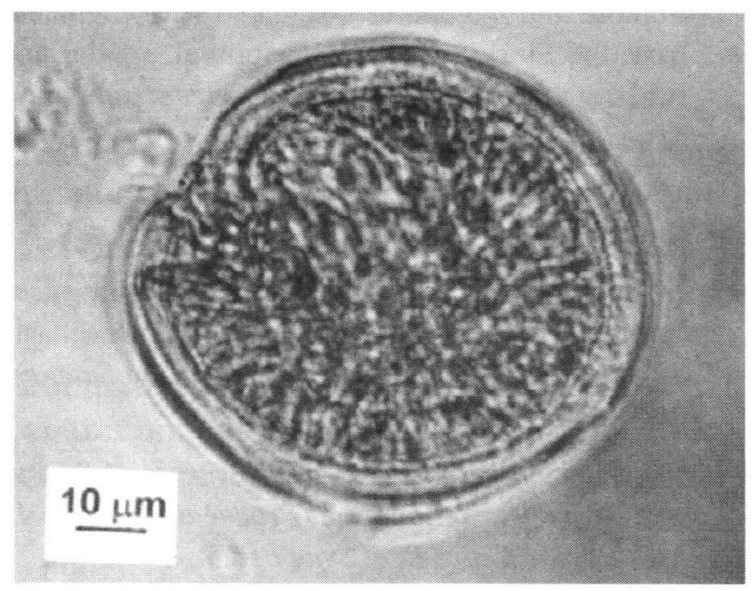

Figure 2. Gambierdiscus toxicus.

Photomicrograph by : Riani Widiarti

This research was constructed to minimize macroalgae variability by limiting the collection for only species from Padina spp. and Sargassum spp. those species of macroalgae were found more abundantly on the reef flat compared to other macrolagae species. Beside that, the morphology of Padina spp. and Sargassum spp. were bushy

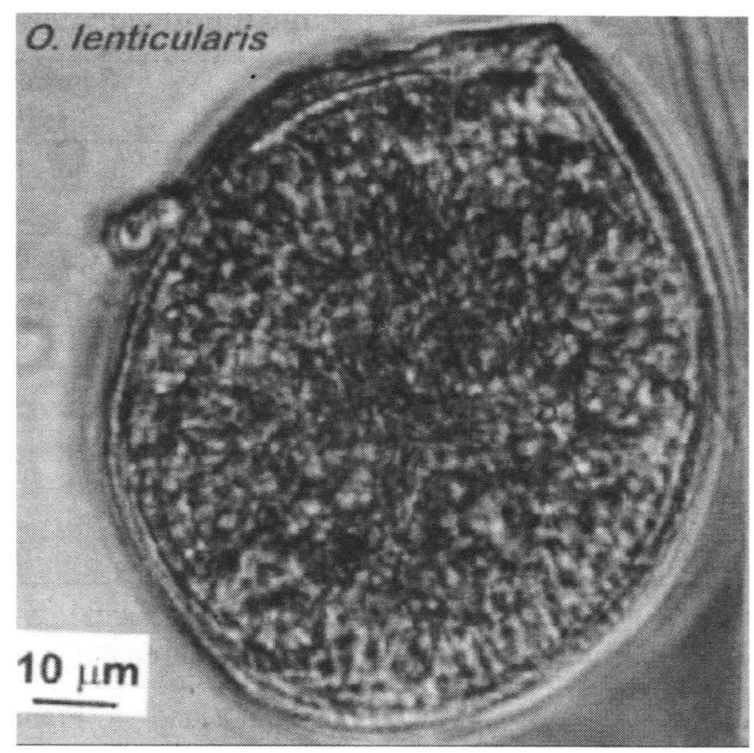

Figure 3. Ostreopsis lenticularis. Photomicrograph by: Riani Widiarti

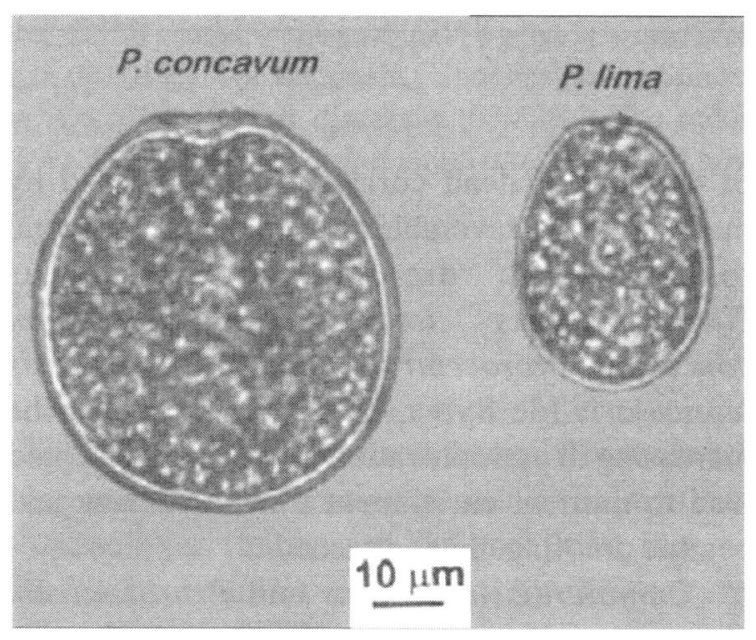

Figure 4. Prorocentrum concavum (left) and P. lima (right)

Photomicrograph by: Riani Widiarti

and had many structural interstices. Benthic dinoflagellate assemblages were found commonly associated with foliose or filamentous macroalgae, especially with structural interstices (Steidinger and Baden, 1984).

Most of the benthic dinoflagellates from both locations was found in Pramuka Islands District. This could be explained by the condition of the location itself. Pramuka Islands District is located in the Inhabited Zone of the National Park, where human activities on the area were relatively high. The intensive activities could cause damage on coral reef and increased eutrophication on the areas. It has been pointed out that the occurrence 
Table 1. The density of benthic dinoflagellates cells per $100 \mathrm{ml}$ of macroalgae wet volume

\begin{tabular}{|c|c|c|c|c|c|c|}
\hline $\begin{array}{l}\text { Macrolagae } \\
\text { species }\end{array}$ & \multicolumn{2}{|l|}{ Island } & $\begin{array}{c}\text { Gambierdiscus } \\
\text { toxicus }\end{array}$ & $\begin{array}{c}\text { Prorocentrum } \\
\text { concavum }\end{array}$ & $\begin{array}{l}\text { Prorocentrum } \\
\text { lima }\end{array}$ & $\begin{array}{l}\text { Ostreopsis } \\
\text { lenticularis }\end{array}$ \\
\hline \multirow[t]{4}{*}{ Padina spp. } & \multicolumn{2}{|c|}{ Penjaliran Barat Island } & 1 & 107 & 254 & 51 \\
\hline & \multirow{3}{*}{$\begin{array}{l}\text { Pramuka } \\
\text { Islands } \\
\text { District }\end{array}$} & Pramuka Island & 0 & 166 & 339 & 861 \\
\hline & & Semak Daun Island & 0 & 171 & 190 & 166 \\
\hline & & Panggang Island & 19 & 407 & 1518 & 0 \\
\hline \multirow[t]{4}{*}{$\begin{array}{l}\text { Sargassum } \\
\text { spp. }\end{array}$} & \multicolumn{2}{|c|}{ Penjaliran Barat Island } & 17 & 162 & 66 & 176 \\
\hline & \multirow{3}{*}{$\begin{array}{l}\text { Pramuka } \\
\text { Islands } \\
\text { District }\end{array}$} & Pramuka Island & 60 & 20 & 70 & 50 \\
\hline & & Semak Daun Island & 0 & 792 & 344 & 641 \\
\hline & & Panggang Island & 0 & 0 & 0 & 0 \\
\hline
\end{tabular}

Table 2. Environmental parameters measurement at sampling sites

\begin{tabular}{|l|c|c|c|c|}
\hline & Penjaliran Barat Island & Pramuka Island & Semak Daun Island & Panggang Island \\
\hline Transparency $(\mathrm{m})$ & 7 & 8 & 8,5 & 7 \\
\hline Temperature $\left({ }^{\circ} \mathrm{C}\right)$ & 30,3 & 30,5 & 31,5 & 30,5 \\
\hline Salinity $(\%)$ & 28 & 34 & 31 & 31 \\
\hline
\end{tabular}

of damage or dead coral surfaces covered by macroalgae is a favorable growth factor for several toxic benthic dinoflagellates such as Gambierdiscus toxicus, Prorocentrum concavum, Prorocentrum lima, and Ostreopsis lenticularis (de Sylva, 1994). Meanwhile, the increasing of eutrophication in the reef area could lead to nutrient enrichment for macroalgae and benthic dinoflagellates attached.

Gambierdiscus toxicus and Prorocentrum concavum cells were most abundant on Sargassum spp., whereas Prorocentrum lima and Ostreopsis lenticularis on Padina spp (Table 1.). Habitat or substrate specialization may occur in benthic dinoflagellate community (Bomber et al., 1985). The habitat separation among species may be due to competition for space on macroalgae or to characteristics of the microorganisms themselves. Some species'could use environmental condition much more efficiently than other species at the same area (Smith, 1980).

Substrate preferences in benthic dinoflagellate community, depends not only on specific condition of the macroalgae as a host, but also on favorable environmental factors which influenced either the macroalgae or the attached microorganisms themselves. This research showed that the benthic dinoflagellates collected were suitable to grow in an environmental condition with temperature of 30.3
$-30.5{ }^{\circ} \mathrm{C}$, salinity $28-34 \%$, and transparency between $7-8.5$ meter depth (Table 2).

\section{REFERENCES}

Bomber, J.W., D.R. Norris, and L.E. Mitchell. 1985. Benthic dinoflagellates associated with Ciguatera from the Florida Keys. II. Temporal, spatial and substrate heterogeinity of Prorocentrum lima. Elsevier Science Publishing, New York: 45-50.

Coremap. 2006. http://www/coremap.or.id/ Kondisi\%2DTK

de Sylva, D.P. 1994. Distribution and ecology of ciguatera fish poisoning in Florida, with emphasis on the Florida Keys. Bulletin of Marine Science, 54(3): 944-954.

Estradivari, and S. Yusri. 2006. Coral reefs of Seribu islands, Western Indonesia. Proceedings of the $1^{\text {st }}$ Asia Pacific Coral Reef Symposium: 1-11.

Randall, J.E. 1958. A review on Ciguatera, tropical fish poisoning, with a tentative explanation of its cause. Bulletin of Marine Science of Gulf and Carribean, 8: 237-267.

Smith, R.L. 1980. Ecology and field biology. $3^{\text {rd }} \mathrm{ed}$. Harper \& Row Publishers, New York: 834pp.

Steidinger, K.A. and D.G. Baden. 1984. Toxic marine Dinoflagellates. In: D.C. Spector (ed.). Dinoflagellates. Academic Press, New York: 201261. 